\title{
EDUCATIONAL CULTURE AS AN INTEGRAL SOCIAL PHENOMENON
}

\author{
Larisa Maslikhova ${ }^{1}$, Alexander Pogorelsky ${ }^{2}$, Umidjon Boymatov ${ }^{3}$ \\ ${ }^{1}$ Candidate of Historical Sciences, Associate Professor, Voronezh State Technical University, \\ 20 years of October Street, 84, Voronezh, Russia, E-mail: maslikhova@vgasu.vrn.ru \\ ${ }^{2}$ Candidate of Historical Sciences, Associate Professor, Voronezh State Technical University, \\ 20 years of October Street, 84, Voronezh, Russia, E-mail: pogorelsky@mail.ru \\ ${ }^{3}$ Assistant, Voronezh State Technical University, 20 years of October Street, 84, Voronezh, Russia, \\ E-mail: u.boimatov@yandex.ru
}

\begin{abstract}
The possibilities of civilizational development of the country are largely determined by the level of educational culture of the society. The educational culture of a society determines both the motivational sphere of human activity and the social orientation of all social transformations. Education, culture and society are the three most important components of the educational culture of a society. However, the initial and system-forming element in this integral concept is the concept of "culture". Also of great importance for the formation of the educational culture of society is the ethnic mentality, which in this approach can be considered as an archetype, a cultural paradigm.
\end{abstract}

Keywords: educational culture, ethnic mentality, archetype, cultural paradigm.

\section{INTRODUCTION}

In our opinion, the possibilities of civilizational development of the country are largely determined by the level of educational culture of the society. It determines the motivational sphere of human activity, the social orientation of all social transformations. The purpose of this article is to characterize the educational culture of society as an integral social phenomenon and determine its role in public life.

Education, culture, and society are fundamental characteristics of sociality that determine the most important aspects of a person's life and have a significant impact on the state and development of civilization. The study of the interaction of these fundamental components allows us to understand many patterns of social development. In our opinion, the concept of educational culture of society makes it possible to develop an integral image, where the integral is characterized through the close interaction of its main elements: education, culture and society and is a system object. The simplest and most productive way to develop such a concept, in our opinion, is to isolate in each of these elements of sociality essential characteristics that suggest their organic interaction. 


\section{METHODOLOGY}

The initial system-forming element in this integral concept is the concept of "culture". There are different interpretations of culture.

We support the opinion of those who believe that culture is not an independent social system, and not a sphere of society. Culture, in the broadest sense of the word, is a specific quality of society that distinguishes it from other material systems and characterizes all that humanity has created in the process of mastering the surrounding world. At the same time, culture is a specific aspect of the wealth created by man, thereby expressing the social value of the material and spiritual goods produced by man. Culture characterizes all aspects of human existence. In this sense, culture appears as the ontological basis of human existence. This is a General philosophical approach to culture.

\section{DISCUSSION}

From a socio-philosophical point of view, culture is understood as a specific, genetically non-inherited set of means and methods, forms, patterns and orientations of interaction between people and their environment, which they develop in their joint life to support certain structures of activity and communication. The famous American sociologist B. Malinovsky believed that culture is mainly an instrumental system through which a person puts himself in the best position to solve specific and specific tasks that arise in the process of life, a way to resolve life's concerns. The essence of a person's life concerns is an adequate existence in objectively existing life circumstances, in forming their own special way of influencing them, in developing their own style of entry, stay, activity and exit from various life situations (in the broadest sense). "Culture is nothing more than a person's interpretation of their own life, a set of successful or unsuccessful decisions that they make in the process of overcoming difficulties and needs... And since these solutions are intended for genuine problems, they are also genuine. These are ideas, assessments, human aspirations, various approaches in philosophy, art, law, etc. "Culture consists of objects, activities and positions that exist as a means to achieve a certain goal. And in culture, everything is connected to everything else - all elements are interdependent.

In modern philosophy, in the interpretation of culture, a structural-semiotic approach to the definition of culture is widely spread, which understands "culture" primarily as a set of sign or symbolic systems that need to be deciphered. In this sense, culture is a world of shared symbols, words and structures of a certain language, and socio - cultural reality is a meaningful text. Culture is understood in such concepts as language in the broadest sense. "In modern semiotic concepts, the symbol becomes, therefore, almost the only carrier of culture, embodying its extra-natural essence, conventional, intersubjective value. In its conventional, symbolic form, we think of a sensuous generalization and visual expression of a spiritual substance that cannot be adequately reproduced. The evocative act of symbolizing the ideal becomes a universal cultural action" from the point of view of the structural-semiotic approach, in all that arises and exists in the world in an unnatural and unnatural way, that is, thanks to man, and constitutes the area of his cultural being, somehow there is already a " life of consciousness". But only in symbols are the conditions of its potential continuity concentrated. Symbolic structures turn out to be unique formations that can generate acts of understanding and consciousness. They are located inside the culture, forming its core, around which all human cultural activities are carried out. Symbols bear on themselves such main functions of culture as the structuring of human existence and sense-making. In other words, the symbolic activity of a person is what makes people, creators of culture. This unique ability to create signs and symbols of the surrounding reality and transmit them in time and space is the basis of the symbolic concept of culture. The origins of culture from the standpoint of this approach - in the ability of man to mass, systematic and permanent symbolization, that is, in the ability to create a kind of artificial world around us, denoting reality with certain symbols. Language, science, art, religion, and myths are all parts of the symbolic universe in which man lives. In its proper cultural existence, it can no longer deal directly with things, but interacts with them only through artificial means, language forms, artistic images, mythological symbols, and religious rites. The main role, the decisive influence on people's lives, their relationships and actions, is assigned here, first of all, to language, which generates all other forms of culture and social institutions.

One of the leading structures of culture is such an essential and stable spiritual sphere as values. In fact, the value hierarchy in each culture in time and space has its own special appearance, its own specifics: each culture is a kind of value world. The same element of culture is of different value to people of different eras and generations, different regional and national cultures. In General, the structural-semiotic approach interprets symbols, ideas and values as a "cultural code", similar to the genetic code that determines the program of behavior of the individual and communities that constitute society. Intellectual level, system 
thinking, emotional state, values of the person, era, way of seeing the world are encoded in the culture and act as a form of spiritual communication of generations. The leading being basis of culture, ordering its being as a whole and its separate phenomena, is the meaning, understood as a structure that States the existence of phenomena in the form of cultural phenomena. Culture is a system of meanings that determine people's thinking and behavior. Since culture is immanent to man, its leading component is the meanings that determine the actual human relationship with the world. Science, art, literature, values, and life orientations should be considered through meaning. It is by the meaning expressed in language and dispersed across various spheres of socio-cultural reality that the latter gathers into a single whole and acquires an integral image. Culture is understood as a system of meanings that determine the behavior of people and are found in the ways of using and understanding the tasks of language. Culture as a social phenomenon is the total spiritual experience of mankind, accumulated over the entire time of its existence, constantly updated, implemented in various ways in everyday life and replenished in multidimensional human activities, embodied in its extremely diverse products.

The concept of "educational culture of society" implicitly includes some qualitative characteristics of society. The leading characteristic of the educational culture of the society is the national and state affiliation of this culture. From our point of view, it is advisable to conduct research of educational culture not of abstract society, but of concrete - Russian (German, French, etc.) society. This means that in the national-state complex, the researcher needs to identify such fundamental structures that have a decisive influence on the educational culture of a given society. In our opinion, such structures are the national mentality, the cultural paradigm and the educational paradigm. Under the concept of mentality in this case we understand a spiritual mindset of people of a particular country or region, sustainable fundamental structures of consciousness and subconsciousness, certain well-established forms of perception inherent in any group of people that define the General features of the attitudes and behaviors of these people in relation to the phenomena of being. The mentality manifests itself in positions, value orientations, worldview and behavioral stereotypes, historical traditions, people's way of life, and language. Formed in the course of the historical process, the mentality forms the spiritual and behavioral specificity that makes representatives of one nation unlike representatives of other Nations, and because of this, it becomes an important factor in the selfidentification of a particular community.

The ethnic mentality is of great importance for the formation of the educational culture of the society.

The concept of "mentality" describes the stable socio-psychological foundations of culture, which perform a programming function, serve as a matrix, a model of cultural activity of people in a long time period. Cultural paradigms serve as a matrix and model of this activity for small time periods.

As N. B. Bakach rightly notes, "the concept of" cultural paradigm " reflects a certain semantic unity of culture at a specific time period, a specific structure of culture during relatively small periods of the cultural process." with this approach, the Mentality can be considered as an archetype, the cultural paradigm as a cultural type.

The cultural paradigm contains the commonality that makes up the unity of a specific cultural and historical epoch and finds its expression in different spheres of culture, in the life of different social groups. Bearers of the cultural paradigm have a common approach to life, a common sense of it, and may belong to different social groups.

This is a cultural model that subjects are guided by in the process of their own identification, that is, in the process of discovering and implementing their cultural self through the development of a specific model for setting and solving life tasks.

Various social communities and institutions also play a significant role in the functioning of culture. One of these subjects is the generation, whose interaction is an important element of the mechanism of the civilizational process. The concept of "generation" itself is rather vague, but culturally it can be defined as a set of peers United by a common worldview, common ideals and common goals. Generation is not only a social community, but also a social institution. Generation as a social institution can be defined as follows: it is a naturally occurring and historically long-lasting and stable set of citizens, which has the characteristics of family-hereditary or socio-age differentiation of powers and social roles, internal differentiation of individualpersonal or group continuity and representation, coherence of self-renewing interactions of subjects and selfregulation.

Each human generation is formed in close contact with the previous ones. This is the result of a conservative mechanism or inertia of culture and a condition for its vitality and continuity. Therefore, in our opinion, as a unit of cultural time, we should consider not one, but about two or three generations. Two generations are carriers of the cultural paradigm precisely because of the stagnating forces, the peculiar laws of self- 
preservation of culture. In any new generation, its essential characteristics are laid down and predicted by the previous generation.

The concept of "culture" is closely related to the concept of "education". According to I. S. Hessen, there is an exact correspondence between education and culture: "Education is nothing but the culture of the individual". Thus, education is interpreted as a cultural process aimed at the spiritual development of the individual. In contrast to spontaneous forms of socialization, education focuses on meaningful, conscious introduction to certain cultural values, initially group, and then socially significant. Moving further away from focusing on the development of narrow professional skills, society over time develops it as a specific area in which the introduction to these cultural values becomes the most optimal.

The specificity of education is precisely that the processes of training and education are not just purposeful, but in a certain way oriented.

Thus, education is the leading and defining beginning of socialization, the main instrument of cultural succession of generations, precisely because it has a reflexive character, reproduces the main trends and characteristic features of social development in its content, organization, structure.

The educational culture of society at each specific historical stage of its development is formed on the basis of a certain educational paradigm. From Kuhn's point of view, the paradigm is a system of theoretical, methodological and value - based attitudes accepted as a model for solving scientific problems and shared by all members of the scientific community at this stage of historical development.

The educational paradigm, as well as the scientific paradigm, is formed in the educational community and performs a normative function in this community. The educational paradigm is a cultural model that the subjects of educational activity are guided by. From this point of view, the educational paradigm should be considered as a model of setting and general approach to solving educational problems. In other words, the educational paradigm is a cultural code that defines the worldview of thinking and behavior of people included in the system of educational activities. It acts as the leading way of being of the Institute of education, being its internal semantic core.

\section{RESULTS}

Thus, the educational culture of society is an objective qualitative indicator of the subjects of social activity of the individual, society, and the state and expresses the nature and level of social activity of people. In this context, educational culture is considered not just as an indicator of the level of education of the country's population, but as one of the important indicators of the development of society at a particular historical stage.

\section{CONCLUSION}

On the basis of the above, the educational culture of a society can be defined as a specific sphere of public life that expresses the side (facet) of national culture, its specific qualitative state that characterizes the level of development and implementation of the activities of various subjects for the preservation, reproduction and development of national culture in accordance with a certain system of values at each specific historical stage of the existence of this culture.

\section{REFERENCE LIST}

Demyanko V. Z. (2006) Paradigm with a human face // Language personality: text, dictionary, image of the world. Moscow: RUDN Publishing house. Pp. 391-414 (in Russian).

Lichkova V. A. (1991) Concept of evocative language of culture // Linguistics: interaction of concepts and paradigms. Kharkiv. Issue 1, part 2. Pp. 306-311. (in Russian).

Mantatova Larisa.(2204) Value bases of modern civilizational development: Dis. of doctor of Philos. Sciences: 09.00.11: Ulan-Ude. 322 p. (in Russian).

Maslikhova L. I., Petrenko V. R., Korshunova S. A. (2019) Achievements of technical education of the Voronezh region as a guarantee of successful development of the country and the region (rev. On the book: 110 years of technical education of the voronezh region : anniversary edition. Voronezh : VSTU publishing house, 2018. 240 p). Bulletin of the Voronezh state University. Series: Problems of higher 
education № 4. Pp. 114-117. (in Russian).

Ortega y Gasset X. Selected works: TRANS. from Spanish / Comp., Preface. and the total ed. of A. M. Rutkevicha. Moscow: publishing house "All the World", 1997. - P. 303 (in Russian).

Radugina O. A. ( 2007) The Concept of educational culture of society (setting the problem) / / Scientific notes of the Russian state social University.Moscow. № 1. P. 98-105 (in Russian).

Radugina O. A. (2008) The Role of educational culture of society in the formation and development of Russian civilization // Modernization of the educational culture of society in the conditions of modern socio-cultural crisis: a collective monograph / Yu. V. Akhromeeva, Yu.G. Golub, V. A. Zhdankin, S. A. Korshunova, V. N. Pervushina, L. S. Perevozchikova and others / ed. by A. A. Radugin. Voronezh: Voronezh. state arch. - builds. UN-t. P. 113-129 (in Russian).

Radugina O. A. (2012). Basic paradigms of education and moral education of the nobility in the educational culture of Russian society // Scientific problems of humanitarian research. №. 4. Pp. 229-305. (in Russian).

Radugina O. A. (2016) the Nobility as a subject of secularization of Russian society: autoref... dis. Doct. Philos.): Voronezh. 35 p. Ivanov A.A. (1999) Russian classical philosophy. From FM Dostoevsky to I.A. Ilyin. M. Dialog. MGU. 112 p. (in Russian).

Stepanov A. A. (2013) Time and "applied philosophy": on the question of theoretical and socio-cultural prerequisites of the philosophical and pedagogical concept of S. I. Gessen // Bulletin of Tomsk state pedagogical University. Issue 9 (137). Pp. 222-228. (in Russian). 